\title{
PERLINDUNGAN HUKUM PERJANJIAN KEMITRAAN PENGADAAN BARANG/JASA PEMERINTAH PADA BIDANG KONSTRUKSI
}

\author{
Zaenal Arifin, Soegianto, Diah Sulistiyani RS \\ Magister Hukum Universitas Semarang, Semarang \\ zaenal@usm.ac.id
}

\begin{abstract}
Abstrak
Penelitian ini bertujuan untuk menganalisis, mengetahui dan memahami perlindungan hukum perjanjian kemitraan pengadaan barang/jasa pemerintah pada jasa konstruksi sesuai dengan Peraturan Presiden No 16 Tahun 2018 tentang Pengadaan Barang/Jasa Pemerintah dan bagaimana kelemahan dan solusi atas pelaksanaan perjanjian kemitraan pengadaan barang/jasa pemerintah pada jasa konstruksi. Penelitian ini mengunakan metode pendekatan yuridis normatif. Hasil dari penelitian ini Perlindungan hukum dalam perjanjian kemitraan pengadaan barang/jasa pemerintah ini berarti dapat memberikan kepastian hukum bagi para pihak. Perlindungan hukum perjanjian kemitraan pengadaan barang/jasa pemerintah telah diatur dalam KUH Perdata, Undang-Undang No 2 Tahun 2017 tentang Jasa Konstruksi, Undang-Undang No 20 Tahun 2009 tentang UMKM dan Peraturan Pemerintah No 17 Tahun 2013 tentang Pelaksanaan Undang-Undang No 20 Tahun 2008 tentang UMKM, Perpres No 16 Tahun 2018 tentang Pengadaan Barang/Jasa Pemerintah dan Peraturan LKPP No 9 Tahun 2018 Tentang Pedoman Pelaksanaan Pengadaan Barang/Jasa Melalui Penyedia. Perlindungan tersebut berupa keharusan perjanjian kemitraan harus dibuat secara tertulis sebagai usaha untuk menghindari adanya perselisihan dan sengketa dan diakuinya perjanjian kemitraan sebagai bukti pengalaman pekerjaaan yang sangat bermanfaat bagi UMKM.
\end{abstract}

Kata kunci : Kemitraan; UMKM; sub kontrak; konstruksi 


\title{
LEGAL PROTECTION OF GOVERNMENT GOODS / SERVICES PARTNERSHIP AGREEMENT IN THE FIELD OF CONSTRUCTION
}

\author{
Zaenal Arifin, Soegianto, Diah Sulistiyani RS \\ Master of Law, Semarang University, Semarang \\ zaenal@usm.ac.id
}

\begin{abstract}
This study aims to analyze, know and understand the legal protection of the partnership agreement on the procurement of goods / services of the government in construction services in accordance with Presidential Regulation No. 16 of 2018 on Procurement of Government Goods / Services and how the weaknesses and solutions to the implementation of the partnership agreement on procurement of goods / services of the government in construction service. This study uses a normative juridical approach. The results of this study Legal protection in the partnership agreement for the procurement of goods / services of this government means it can provide legal certainty for the parties. Legal protection of government goods / service partnership agreements has been regulated in the Civil Code, Law No. 2 of 2017 concerning Construction Services, Law No. 20 of 2009 concerning SME and Government Regulation No. 17 of 2013 concerning Implementation of Law No. 20 of Year 2008 concerning UMKM, Perpres No. 16 of 2018 concerning Procurement of Government Goods/Services and LKPP Regulation No. 9 of 2018 concerning Guidelines for the Implementation of Procurement of Goods / Services Through Providers. Such protection in the form of a partnership agreement must be made in writing as an effort to avoid disputes and disputes and the recognition of the partnership agreement as evidence of work experience that is very beneficial for SME.
\end{abstract}

Keywords: Partnership; SME; sub kontrak; konstruksi 


\section{A. PENDAHULUAN}

Di negara-negara yang berkembang, pembangunan infrastruktur dan pembangunan manusia menjadi andalan untuk menjadi negara maju, karena merupakan salah satu sektor penggerak perekonomian dengan kemampuannya : (i) menyerap tenaga kerja dalam jumlah besar dalam kurun waktu yang cukup lama, (ii) dan karenanya dapat membantu peningkatan distribusi pendapatan, (iii) menstimulasi sektor produksi lain dengan dampak berganda. ${ }^{1}$

Berdasarkan amanat Undang-Undang Dasar Negara Republik Indonesia 1945, negara berkewajiban melayani setiap warga negara untuk memenuhi hak dan kebutuhannya dalam kerangka pelayanan umum yang layak. Untuk menyelenggarakan pelayanan umum yang lebih baik bagi semua warga negara, pemerintah harus berperan aktif dalam menyediakan dan memfasilitasi kebutuhan umum yang bermanfaat bagi masyarakat luas, yang dapat diakses oleh semua anggota masyarakat melalui pengadaan barang /jasa yang transparan dan akuntabel. Sebagai upaya untuk memenuhi hak dan kebutuhan pelayanan umum yang layak diperlukan landasan hukum yang kokoh dalam proses pengadaan barang/jasa. Pengadaan barang/jasa pemerintah harus menjamin kepastian hukum dan memberikan perlindungan bagi setiap warga negara dan masyarakat dari penyalahgunaan wewenang di dalam penyelenggaraan pengadaan barang/jasa guna menciptakan iklim pengadaan barang/jasa yang kondusif. $^{2}$

Kemitraan dalam pengadaan barang/jasa pemerintah diatur dalam dalam Peraturan Presiden No 16 Tahun 2018 tentang Pengadaan Barang/Jasa Pemerintah, kemitraan diatur di Pasal 65 (6) yang berbunyi "Penyedia usaha non-kecil yang melaksanakan pekerjaan dapat melakukan kerja sama usaha dengan usaha kecil dalam bentuk kemitraan, subkontrak, atau bentuk kerja sama

\footnotetext{
${ }^{1}$ Agus G Kartasasmita, "Makalah Pengadaan Barang dan Jasa Menurut Pelaku Usaha”, Jakarta, 2006, Bappenas, hlm 2.

${ }^{2}$ Adi Susila, "Mencermati Rancangan Undang-Undang Pengadaan Barang dan Jasa Pemerintah”, Jurnal AKP, Volume1 Nomor 1, Bekasi, 2012, Fakultas Ilmu Sosial dan Ilmu Politik Universitas Islam 45, hlm 40. DOI: https://doi.org/10.33558/akp.v1i1.572
} 
lainnya, jika ada usaha kecil yang memiliki kemampuan di bidang yang bersangkutan".

Perusahaan kontraktor dalam menjalankan tugasnya juga harus menyediakan peralatan-peralatan sendiri yang diperlukan untuk menangani proyek yang dibebankan kepadanya, oleh karena itu, dalam menjalankan pekerjaannya perusahaan kontraktor biasanya membagi pekerjaannya dengan perusahaan kontraktor lain yang mempunyai keahlian yang diperlukan untuk menyelesaikan suatu pekerjaan yang tidak dikuasai oleh kontraktor utama. Perusahaan yang menjalankan pekerjaan kontraktor dari kontraktor lainnya biasa disebut sub kontraktor. ${ }^{3}$

Perjanjian kemitraan mempunyai peran yang penting dalam pembangunan nasional. Lancar atau tidaknya pelaksanaan pembangunan juga dapat dipengaruhi oleh hasil dari pelaksanaan pekerjaan kemitraan tersebut. Kemitraan harusnya menjadi upaya untuk meningkatkan dan melancarkan pembangunan nasional dan bukan sebagai bagian dari masalah dalam pembangunan tersebut. Proses tender pekerjaan konstruksi yang dilakukan oleh pemerintah, khusus mengenai subkon idealnya sudah ditentukan sejak tahap perencanaan. Proses pengadaan barang/jasa pemerintah melalui proses tender untuk mencari siapa yang akan menjadi main kontraktor, namun, kriteria subkontraktor yang seperti apa tidak begitu detail disyaratkan. Bahkan bentuk atau suatu keharusan perjanjian kerja antara main kontraktor dengan subkontraktor kurang diperhatikan. Misalnya mengenai jaminan/guarantee atau pemeliharaan yang dikerjakan oleh subkontraktor. ${ }^{4}$

Kontrak dalam terma hukum diartikan sebagai sebagai suatu hubungan personal yang berkelanjutan, pada dasarnya diatur oleh seperangkat normanorma. Norma-norma tersebut dapat memerintahkan, mewajibkan atau melarang

\footnotetext{
${ }^{3}$ Mitha Miranda Sari, “Kedudukan Dan Tanggung Jawab Hukum Pihak Sub Kontraktor Pada Perjanjian Pengadaan Barang/Jasa Pemerintah”, Jurnal Ilmiah Ilmu Hukum Kenotariatan Repertorium Volume 4 No 2 2015, Palembang, 2015, Fakultas Hukum Universitas Sriwijaya, hlm 5. DOI:http://dx.doi.org/10.28946/rpt.v4i2.163

${ }^{4}$ Ajik Sujoko, "Permasalahan Subkontrak Pada Pekerjaan Konstruksi di Pemerintah", Administrasi Law \& Governance Journal Volume 2 Issue 3, 2019, Fakultas Hukum Universitas Diponegoro, 2019, Semarang, hlm 416. DOI: https://doi.org/10.14710/alj.v2i3.413\%20-\%20435
} 
perilaku-perilaku tertentu. Pada pelaksanaan perilaku tertentu seringkali digantungkan pada perilaku-perilaku atau kondisi-kondisi tertentu. Perilaku yang menyimpang dapat diancam suatu disinsentif (sanksi), dan perilaku yang baik dapat menerbitkan hak untuk memperoleh insentif. ${ }^{5}$ Perjanjian kemitraan yang ideal adalah perlu adanya ahli hukum seperti notaris atau pengacara yang dapat memberikan pendapat maupun nasihat-nasihat hukum bisa menyertai para pelaku kemitraan dan membuatkan akta perjanjian otentik yang akan menjadikan kekuatan hukum yang sempurna bagi kemitraan tersebut. Sehingga para pihak yang ada dalam perjanjian kemitraan tersebut saling terlindungi hak dan kewajibannya

Penelitian ini lebih fokus membahas mengenai perlindungan hukum perjanjian kemitraan pada bidang jasa konstruksi yang disesuaikan dengan peraturan yang terbaru yaitu Peraturan Presiden Nomor 16 Tahun 2008 tentang Pengadaan Barang/Jasa Pemerintah dan Undang-Undang No 2 Tahun 2017 tentang Jasa Konstruksi. Adanya pembaruan pengaturan yang mengatur tentang kemitraan dalam pengadaan barang/jasa pemerintah tentunya akan sangat menarik untuk diteliti dan dibahas.

Menurut Undang-Undang Nomor 20 Tahun 2008 tentang Usaha Mikro Kecil dan Menengah (UMKM), pengertian kemitraan adalah kerjasama dalam keterkaitan usaha, baik langsung maupun tidak langsung, atas dasar prinsip saling memerlukan, mempercayai, memperkuat, dan menguntungkan yang melibatkan pelaku Usaha Mikro, Kecil dan Menengah dengan Usaha Besar. Kemitraan dalam proses pengadaan barang/jasa dan pemerintah adalah sebagai suatu hubungan hukum kerjasama antara dua pihak yang didasari oleh prinsip saling menguntungkan dan saling menghargai diantara mereka. Kemitraan dilakukan dalam bentuk perjanjian tertulis. Kemitraan memungkinkan para

\footnotetext{
${ }^{5}$ Agri Chairunisa Isradjuningtias, "Force Majeure (Overmacht) Dalam Hukum Kontrak (Perjanjian) Indonesia", Junal Veritas et Justitia Vol 1 No 1 2015, Jilid 46 No. 1, Januari 2017, Fakultas Hukum Universitas Katolik Parahyangan, 2015, Bandung, hlm 138-139.

DOI: https://doi.org/10.25123/vej.1420
} 
pihak untuk saling menutupi dan memberi dalam menghadapi kekurangan diantara mereka.

Penelitian yang dilakukan oleh Mitha Miranda Sari dkk yang berjudul Kedudukan dan Tanggung Jawab Hukum Pihak Kontraktor Pada Perjanian Pengadaan Barang/Jasa Pemerintah yang dimuat oleh Jurnal Ilmiah Hukum Kenotariatan Repertorium Universitas Sriwijaya Tahun 2015 lebih fokus terhadap tanggung jawab hukum sub kontraktor tentang terjadinya wanprestasi oleh sub kontraktor adalah hanya kepada main kontraktor dalam sub kontrak, tetapi tidak kepada pihak pengguna barang/jasa dalam hal ini PPK/KPA (pemerintah), sedangkan pihak main kontraktor bertanggaung jawab penuh terhadap pengguna barang/jasa (pemerintah) jika terjadi wanprestasi dalam pelaksanaan prestasi yang diperjanjikan dalam main kontrak pengadaan barang/jasa pemerintah.

Sedangkan Dea Putri Fajarini dalam judul penelitian Subkontrak Dalam Pengadaan Barang/Jasa Pemerintah yang dimuat di Jurnal Mimbar Keadilan Tahun 2019 pada penelitiannya lebih fokus pada syarat keabsahan perjanjian sub kontrak pada pengadaan barang/jasa pemerintah serta akibat hukum adanya perajanjian sub kontrak terhadap para pihak. Hasil penelitiannnya tersebut adalah adanya syaratsyarat yang harus dipenuhi dalam melaksanakan sub kontrak, dan sub kontraktor tidak bertanggung jawab secara langsung kepada pengguna barang tetapi kepada kontraktor utama. ${ }^{6}$

Keberpihakan pemerintah kepada sektor UMKM ini sangat jelas melalui undang-undang ini dikarenakan pemerintah memang sangat berkepentingan untuk melindungi dan mengembangkan sektor UMKM ini yang ditindaklanjuti dengan Peraturan Pemerintah (PP) Nomor 17 Tahun 2013 tentang Pelaksanaan Undang-Undang Nomor 20 tahun 2008. Poin penting yang diatur dalam PP ini adalah peran pemerintah pusat dan pemerintah daerah untuk memfasilitasi pengembangan UMKM. Salah satunya dengan memberikan prioritas kepada

\footnotetext{
6 Dea Putri Fajarini, “Subkontrak Dalam Pengadaan Barang/Jasa Pemerintah", Mimbar Keadilan Volume 12 Nomor 1 Februari 2019 -Juli 2019, Universitas Airlangga, 2019, Surabaya, hlm 69. DOI: https://doi.org/10.30996/mk.v12i1.2168
} 
UMKM untuk ikut serta dalam program pengadaan barang dan jasa yang diadakan oleh pemerintah. Hal lain yang diatur adalah kemudahan perizinan, penyediaan pembiayaan, dan fasilitasi teknologi informasi. ${ }^{7}$

Ada unsur kebaruan dalam pelaksanaan suatu undang-undang tentunya harus diimbangi dengan sosialisasi pada segenap stakeholeder. Undang-undang yang baru tentunya jangan sampai bersingungan dengan aturan lain yang masih berlaku terutama yang berkaitan dengan kemitraan dalam pengadaan barang/jasa pemerintah. Hasil dari penelitian ini diharapkan dapat menjawab mengenai perlindungan hukum dalam perjanjian kemitraan pengadaan barang/jasa pemerintah sekaligus menjawab bagaimana kelemahan-kelemahan yang ada dalam perjanjian kemitraan pengadaan barang/jasa pemerintah sekaligus menemukan solusinya. Tujuan dari penelitian ini adalah untuk mengkaji pelaksanaan perjanjian kemitraan pengadaan barang/jasa pemerintah pada bidang konstruksi dan mengkaji perlindungan hukum perjanjian kemitraan pengadaan barang/jasa pemerintah pada bidang konstruksi.

\section{B. PERMASALAHAN}

Permasalahan yang diangkat dalam penelitian ini yaitu :

1. Bagaimanakah perlindungan hukum perjanjian kemitraan pengadaan barang/jasa pemerintah pada bidang kontruksi?

2. Bagaimanakah pelaksanaan perjanjian kemitraan pengadaan barang/jasa pemerintah pada bidang konstruksi?

\section{METODE PENELITIAN}

Metode pendekatan berguna untuk mendekati obyek dari penelitian atau dalam mengumpulkan data yang diperlukan. Metode pendekatan yang dipergunakan dalam penelitian ini adalah metode pendekatan yuridis normatif, yaitu suatu pendekatan yang berpegang dari segi-segi yuridis/hukum atau peraturan-peraturannya dalam mencari dan mengumpulkan data. Metode pendekatan yuridis normatif ini juga berusaha mensinkronisasikan ketentuan-

${ }^{7}$ Andi Putra Sitorus, "Politik Hukum Perlindungan Usaha Mikro Kecil Menengah (UMKM) Dalam Masyarakat Ekonomi Asean", Doktrina: Journal of Law, Volume 1 Oktober 2018, Universitas Medan Area, Medan, hlm 130. 
ketentuan hukum yang berlaku dengan pelaksanaannya terhadap masalah yang akan diteliti. Penelitian ini didasarkan pada kaidah-kaidah hukum, norma-norma atau peraturan hukum lainnya yang berlaku mengenai dalam perjanjian kemitraan pengadaan barang dan jasa pemerintah..

Deskriptif maksudnya adalah penelitian ini bertujuan memberikan gambaran secara rinci, menyeluruh, dan sistematis mengenai obyek penelitian beserta segala hal yang berkaitan dengannya. Sedangkan analitis mengandung makna mengelompokkan, menghubungkan, dan membandingkan.

Penelitian deksriptif analitis yaitu penelitian yang mendeskripsikan secara terperinci fenomena sosial yang menjadi pokok permasalahan. ${ }^{8}$ Sumber data yang digunakan dalam penelitian ini adalah data sekunder. Data sekunder ini diperoleh melalui studi kepustakaan.

a. Bahan hukum tertier yaitu bahan yang dapat memberikan dukungan seperti penjelasan dan lain sebagainya. Bahan hukmum tertier dapat berupa kamus, ensiklopedia dan lain-lain.

Analisis merupakan langkah terakhir dalam kegiatan penelitian. Data yang telah terkumpul dianalisis untuk mendapat kejelasan masalah yang dibahas. Analisis data dilakukan secara "Normatif Kualitatif", yaitu:

a. Normatif : penelitian ini dilakukan dengan menggunakan peraturanperaturan yang ada. Penelitian ini merupakan penelitian kepustakaan, yaitu penelitian terhadap data sekunder. ${ }^{9}$

b. Kualitatif : penelitian ini dilakukan dengan menggunakan data, mengorganisasikan data, memilah-milahnya menjadi satuan yang dapat dikelola, mensintesiskannya, mencari dan menemukan pola, menemukan apa yang dipelajari, dan memutuskan apa yang dapat diceritakan kepada orang lain. ${ }^{10}$

c.

8 Soerjono Soekanto dan Sri Mamudji,, Pengantar Penelitian Hukum, Jakarta, 1986, UI Press, Jakarta, hlm 10.

${ }^{9}$ Lexy J. Moleong, Metodologi Penelitian Kualitatif Edisi Revisi, Bandung, 2004, PT. Remaja Rosdakarya, hlm 67.

${ }^{10}$ Ibid. 


\section{PEMBAHASAN}

\section{Perlindungan Hukum Perjanjian Kemitraan Pengadaan Barang/Jasa Pemerintah Pada Bidang Konstruksi}

Masih adanya ketidaktahuan mengenai jenis dan arti penting adanya perjanjian kemitraan, terutama bagi para penyedia jasa UMKM, mereka biasanya hanya menurut dan keinginan ataupun perjanjian kemitraan yang disodorkan oleh penyedia jasa non kecil. Mereka tidak mempunyai posisi tawar yang cukup dalam menegosiasi isi surat perjanian kemitraan, atau bahkan dalam menerima pekerjaan mereka tidak mempunyai perjanjian kemitraan. Sehingga para pelaku UMKM tidak terlindungi ketika dalam mengerjakan pekerjaan subkontraktor tidak disertai perjanjian yang adil dan sama-sama menguntungkan kedua belah pihak.

Pada praktiknya, dalam membuat dan melaksanakan suatu perjanjian yang melahirkan kontrak (perikatan), sering kali ditemukan permasalahan. Permasalahan dalam kontrak dapat muncul ketika salah satu pihak tidak menjalankan suatu prestasi atau kewajiban sesuai dengan yang disepakati atau adanya perselisihan mengenai makna-makna redaksi dalam kontrak. Permasalahan yang berakar dari dua hal tersebut sering menimbulkan kerugian pada salah satu atau kedua belah pihak. Pada titik inilah terjadi persengketaan antara pihak-pihak yang mengikatkan diri pada kontrak tersebut. ${ }^{11}$

Menurut Undang-Undang Nomor 20 Tahun 2008 tentang UMKM, usaha mikro adalah usaha produktif milik perorangan dan atau badan usaha perorangan yang memenuhi kriteria :

1) Memiliki kekayaan bersih paling banyak Rp. 50.000.000,- (lima puluh juta rupiah) tidak termasuk tanah dan bangunan tempat usaha; atau

2) Memiliki hasil penjualan tahunan paling banyak Rp. 300.000.000,- (tiga ratus juta rupiah).

\footnotetext{
${ }^{11}$ Muhammad Natsir Asnawi, "Perlindungan Hukum Kontrak Dalam Perspektif Hukum Kontrak Kontemporer", Jurnal Masalah-Masalah Hukum, Jilid 46 No. 1, Januari 2017, Fakultas Hukum Universitas Diponegoro, 2017, Semarang, hlm 56. DOI: 10.14710/mmh.46.1.2017.55-68
} 
Usaha Kecil adalah usaha ekonomi produktif yang berdiri sendiri, yang dilakukan oleh orang perorangan atau badan usaha yang bukan merupakan anak perusahaan atau bukan cabang perusahaan yang dimiliki, dikuasai atau menjadi bagian baik langsung maupun tidak langsung dengan Usaha Menengah atau Usaha Besar yang memenuhi kriteria :

1) Memiliki kekayaan bersih lebih dari $\mathrm{Rp} 50.000 .000$,- (lima puluh juta rupiah) sampai dengan paling banyak Rp 500.000.000,- (lima ratus juta rupiah) tidak termasuk tanah dan bangunan tempat usaha; atau

2) Memiliki hasil penjualan tahunan lebih dari Rp 300.000.000,- (tiga ratus juta rupiah) sampai dengan paling banyak Rp 2.500.000.000,- (dua milyar lima ratus juta rupiah).

Pengertian usaha menengah menurut Undang-Undang No 20 Tahun 2008 tentang UMKM, yaitu usaha ekonomi produktif yang berdiri sendiri, yang dilakukan oleh orang perorangan atau badan usaha yang bukan merupakan anak perusahaan atau cabang perusahaan yang dimiliki, dikuasai, atau menjadi bagian langsung maupun tidak langsung dengan Usaha Kecil atau Usaha Besar dengan jumlah kekayaan bersih atau hasil penjualan seperti kriteria :

1) Memiliki kekayaan bersih lebih dari Rp 500.000.000,- (lima ratus juta rupiah) sampai dengan paling banyak Rp 10.000.000,- (sepuluh milyar rupiah) tidak termasuk tanah dan bangunan tempat usaha; atau

2). Memiliki hasil penjualan tahunan lebih dari Rp 2.500.000.000,- (dua milyar lima ratus juta rupiah) sampai dengan paling banyak Rp 50.000.000,- (lima puluh milyar rupiah).

Penyedia jasa di bidang konstruksi dalam proses pengadaan barang/jasa pemerintah mengacu pada 2 peraturan perundang-undangan yaitu Undangundang Nomor 2 Tahun 2017 tentang Jasa Konstruksi dan Peraturan Presiden No 16 Tahun 2018 tentang Pengadaan Barang/Jasa Pemerintah. Perpres No 16 Tahun 2018 lebih banyak mengatur mengenai teknis pelaksanaan proses pengadaan barang/jasa pemerintah yang dimulai dari proses perencanaan, penganggaran. persiapan tender, pelaksanaan tender, pengumuman pemenang, kontrak, serah terima barang dan pembayaran. 
Adanya kemitraan antara perusahaan yang lebih besar dengan usaha kecil tersebut diharapkan dapat meningkatkan perekonomian karena akan banyak tenaga kerja yang terserap sehingga bisa mengurangi pengangguran dan meningkatkan daya beli masyarakat.

Perjanjian kemitraan pengadaan barang/jasa pemerintah sering dibuat dalam bentuk kontrak standar. Perjanjian baku atau standar lahir sebagai bentuk dari perkembangan dan tuntutan dunia usaha. Kontrak standar telah banyak diterapkan dalam dunia usaha seperti perbankan, lembaga pembiayaan konsumen, dan berbagai bentuk usaha lainya. Kontrak standar atau baku dipandang lebih efisien dari sisi waktu dan biaya. ${ }^{12}$

Undang-undang No 2 Tahun 2017 lebih banyak mengatur tentang kualifikasi usaha jasa konstruksi, penyelenggaraan jasa konstruksi, tenaga kerja jasa konstruksi penyedia jasa, kelembagaan jasa konstruksi, sengketa jasa konstruksi, penyelenggaraan jasa konstruksi yang berkelanjutan, pembinaan jasa konstruksi dan ketentuan sanksi.

Pengaturan kemitraan juga diatur dalam dalam Undang-Undang No 2 Tahun 2017 tentang Jasa Konstruksi, kemitraan diatur dalam Pasal 2 huruf i, dijelaskan bahwa penyelenggaraan jasa konstruksi berlandaskan asas kemitraan.

Pelaksanaan kemitraan antar wilayah provinsi diatur dalam Pasal 6 ayat 1 huruf e yang menjelaskan bahwa gubernur sebagai wakil Pemerintah Pusat di daerah memiliki kewenangan: memfasilitasi kemitraan antara badan usaha Jasa Konstruksi di provinsi dengan badan usaha dari luar provinsi.

Kemitraan antara pengusaha nasional dengan asing diatur dalam Pasal 33 (1) huruf c yang berbunyi Kantor perwakilan sebagaimana dimaksud dalam Pasal 32 huruf a wajib: membentuk kerja sama operasi dengan badan usaha Jasa Konstruksi nasional berkualifikasi besar yang memiliki Izin Usaha dalam setiap kegiatan usaha Jasa Konstruksi di Indonesia.

\footnotetext{
${ }^{12}$ Shidarta, 2000, Hukum Perlindungan Konsumen Indonesia, Grasindo, Jakarta, Terbitan Pertama, hlm 29.
} 
Pelaksanaan kemitraan dengan bentuk sub kontaktor diatur dalam Pasal 53 (1) Dalam penyelenggaraan Jasa Konstruksi, pekerjaan utama hanya dapat diberikan kepada Subpenyedia Jasa yang bersifat spesialis sebagaimana dimaksud dalam Pasal 13 dan Pasal 14. (2) Pemberian pekerjaan utama kepada Subpenyedia Jasa yang bersifat spesialis sebagaimana dimaksud pada ayat (1) harus mendapat persetujuan Pengguna Jasa. (3) Dalam penyelenggaraan Jasa Konstruksi, Penyedia Jasa dengan kualifikasi menengah dan/atau besar mengutamakan untuk memberikan pekerjaan penunjang kepada Subpenyedia Jasa dengan kualifikasi kecil. (4) Penyedia Jasa dan Subpenyedia Jasa wajib memenuhi hak dan kewajiban sebagaimana tercantum dalam Kontrak Kerja Konstruksi.

Pasal 54 (1) Dalam penyelenggaraan Jasa Konstruksi, Penyedia Jasa dan/atau Sub penyedia Jasa wajib menyerahkan hasil pekerjaannya secara tepat biaya, tepat mutu, dan tepat waktu sebagaimana tercantum dalam Kontrak Kerja Konstruksi. (2) Penyedia Jasa dan/atau Subpenyedia Jasa yang tidak menyerahkan hasil pekerjaannya secara tepat biaya, tepat mutu, dan/atau tepat waktu sebagaimana dimaksud pada ayat (1) dapat dikenai ganti kerugian sesuai dengan kesepakatan dalam Kontrak Kerja Konstruksi.

Terjadi ketidaksesuaian dalam penggolongan kualifikasi antara UU No 2 Tahun 2017 yang membagi 3 kualifikasi penyedia jasa yaitu usaha kecil, menengah dan besar. Sedangkan dalam Perpres No 16 tahun 2018 penggolongan kualifikasi usaha hanya menjadi 2 yaitu kecil dan non kecil. Pembedaan golongan kualifikasi ini akan menyulitkan penyedia jasa konstruksi baik untuk mengikuti tender yang aturannya harus mengikuti Perpres No 16 Tahun 2018 tentang Pengadaan Barang/Jasa Pemerintah, maupun pada saat penyedia jasa melakukan kemitraan kerja sama operasi dalam proses tender.

Adanya perjanjian kemitraan, diharapkan hak tiap para pihak akan saling terlindungi. Usaha Mikro Kecil dan Menengah juga mempunyai posisi yang seimbang dengan perusahaan besar dalam isi perjanjian, atau dalam perjanjian kemitraan antara dua atau lebih perusahaan dalam mengikuti pengadaan barang 
dan jasa pemerintah juga mempunyai hak dan kewajiban yang seimbang dalam isi perjanjian. Kemitraan semacam ini diharapkan dapat memberikan manfaat yang lebih luas bagi kesejahteraan masyarakat. Karena perjanjian kemitraan seringkali hanya dibuat sebagai formalitas untuk memenuhi adanya perjanjian dalam kemitraan atau sebagai salah satu syarat saja dalam memenuhi persyaratan yang ada dalam pengadaan barang/jasa pemerintah.

\section{Pelaksanaan Perjanjian Kemitraan Pengadaan Barang/Jasa}

\section{Pemerintah Pada Bidang Konstruksi}

Pengadaan barang/jasa pemerintah di bidang konstruksi terutama untuk golongan kualifikasi Besar/Non Kecil sangat tidak mungkin bila seluruh pekerjaan hanya ditangani oleh satu kontraktor utama, dalam membantu menyelesaikan pekerjaan konstruksi pasti melibatkan subkontraktor atau menjalin kerja sama operasi dengan perusahaan lain. Kerja sama dalam pengalihan atau sebagian pekerjaan tersebut disebut sebagai kemitraan. Kemitraan yang terjadi dalam bidang konstruksi seperti Kerja Sama Operasi (KSO) maupun yang bersifat subkontrak, yaitu penyerahan sebagian pekerjaan dari kontraktor utama kepada subkontraktor yang biasanya dilaksanakan oleh kontraktor dengan kualifikasi menengah atau kecil.

Pengikatan dalam bentuk kontrak konstruksi ini menjadi sangat penting untuk dilakukan mengingat konstruksi dewasa ini merupakan bidang usaha jasa yang banyak diminati oleh anggota masyarakat di berbagai tingkatan, sebagaimana dapat dilihat dari semakin besarnya jumlah perusahaan/badan usaha yang bergerak di bidang usaha penyedia jasa konstruksi. Peningkatan jumlah perusahaan atau badan usaha ini belum diikuti dengan pemahaman oleh perusahaan atau badan usaha terkait dengan landasan filosofis hubungan kontraktual antara pemberi jasa konstruksi dengan penyedia jasa konstruksi dan pengawas jasa konstruksi, prinsip dan norma hukum tahap pembentukan 
kontrak konstruksi, prinsip dan norma hukum tahap pelaksanaan kontrak konstruksi. $^{13}$

Menurut Undang-Undang Nomor 20 Tahun 2008 tentang Usaha Mikro Kecil dan Menengah, pengertian kemitraan adalah kerjasama dalam keterkaitan usaha, baik langsung maupun tidak langsung, atas dasar prinsip saling memerlukan, mempercayai, memperkuat, dan menguntungkan yang melibatkan pelaku Usaha Mikro, Kecil dan Menengah dengan Usaha Besar. Kemitraan dalam proses pengadaan barang/jasa dan pemerintah adalah sebagai suatu hubungan hukum kerjasama antara dua pihak yang didasari oleh prinsip saling menguntungkan dan saling menghargai diantara mereka. Kemitraan dilakukan dalam bentuk perjanjian tertulis. Kemitraan memungkinkan para pihak untuk saling menutupi dan memberi dalam menghadapi kekurangan diantara mereka.

Di Kota Semarang, hampir 70\% anggota Gapensi merupakan golongan menengah dan kecil. Hali ini sesuai dengan penggolongan kualifikasi yang terbagi dalam 7 klasifikasi yang berdasarkan Peraturan LPJK No 2 Tahun 2013 tanggal 15 Januari 2013 membagi kualifikasi usaha jasa kontraktor sebagai berikut :

1. Kualifikasi B2 mempunyai kekayaan bersih > Rp.50 milyar,

2. Kualifikasi B1 mempunyai kekayaan bersih Rp 10 milyar sd Rp50 milyar,

3. Kualifikasi M2 mempunyai kekayaan bersih Rp 2 milyar sd Rp 10 milyar

4. Kualifikasi M1 mempunyai kekayaan bersih Rp.500 jt sd Rp 2 milyar,

5. Kualifikasi K3 mempunyai kekayaan bersih Rp. 350 juta sd Rp 500 juta,

6. Kualifikasi K2 mempunyai kekayaan bersih Rp 50 juta sd Rp 350 juta,

Kualifikasi K1 mempunyai kekayaan bersih Rp 50 juta sd 200 juta.

Sebagian besar anggota Gapensi Kota Semarang tergolong sebagai UMKM, mengingat sebagian besar dari anggota Gapensi Kota Semarang adalah pengusaha kecil dan menengah, mereka mendapatkan pekeraan melalui pekerjaan kemitraan baik itu subkontrak atau kemitraan lainnya.

\footnotetext{
${ }^{13}$ Sugiarto Raharjo Japar, "Prinsip-Prinsip Kontrak Konstruksi Indonesia", Mimbar Yustitia Vol. 2 No.2 Desember 2018, Universitas Islam Darul Ulum, 2018, Lamongan, hlm 192.
} 
Adapun jumlah penyedia barang yang sebaran kualifikasi badan usahanya sebagai berikut: kualifikasi besar 2 sebanyak $0,3 \%$ atau 1 penyedia barang dan jasa, besar 1 sebanyak $3.4 \%$ atau 12 penyedia barang dan jasa, menengah 2 sebanyak $5.7 \%$ atau 20 penyedia barang dan jasa, menengah 1 sebanyak $13.2 \%$ atau 46 penyedia barang dan jasa, kecil 3 sebanyak 18.7\% atau 65 penyedia barang dan jasa, kecil 23 sebanyak $6.6 \%$ atau 1 penyedia barang dan jasa, kecil 1 sebanyak 52.0\% atau 181 penyedia barang dan jasa.

Kemitraan yang dilaksanakan oleh anggota Gapensi Kota Semaarang hanya ada 2 yaitu kemitraan dengan jenis sub kontraktor dan kerja sama operasi (joint operation). Kemitraan dengan model sub kontraktor dilakukan baik oleh penyedia jasa kualifikasi besar kepada penyedia jasa dengan kualifikasi menengah atau kecil maupun sebaliknya. Kontraktor besar yang mengerjakan bangunan gedung memberikan sebagian pekerjaannya kepada penyedia jasa menengah/kecil karena mereka mempunyai spesialisasi pekerjaan seperti interior gedung atau mekanikal/elektrikal.

Begitu pula kontraktor dengan kualifikasi menengah atau kecil yang mengerjakan jembatan/jalan memberikan sebagian pekerjaannya kepada Kontraktor besar yang mempunyai fasilitas Asphal Mixing Plant dan Concrete Mixing Plant. Adanya hubungan salaing menguntungkan diantara para kontraktor besar dan kontraktor kecil seharusnya memberiakn nilai keseimbangan dalam perjanjian kemitraan. Tetapi pada pelaksanaannya seringkali timbul ketidakseimbangan dalam perjanjian kemitraan.

Sedangkan jenis kemitraan kedua yang dilaksanakan oleh angota Gapensi Kota Semarang adalah kerja sama operasi/ joint operation. Model kemitraan ini terdiri dari 2 atau lebih penyedia jasa baik sesama kualifikasi besar atau kecil yang melakukan kerjasama untuk bersama-sama membagi kewajiban, modal, keuntungan dan kapasitasnya untuk memenuhi ketentuan atau spesfikasi yang diminta oleh panitia pengadaan. Penyedia jasa yang kualifikasi dan kapasitas pekerjaannya tidak mencukupi sesuai bidang pekerjaan yang ditenderkan akan melaksanakan kemitraan secara kerjasama operasi. 
Permasalahan lain yang dihadapi oleh anggota Gapensi Kota Semarang dalam perjanjian kemitraan antara lain tidak adanya keseimbangan dalam materi perjanjian kemitraan karena adanya dominasi dari salah satu pihak, karena lemahnya daya tawar dari salah satu pihak. Permasalahan ini terjadi dalam perjanjian kemitraan jenis sub kontraktor. Sedangkan permasalahan perjanjian kemitraan dalam kerjasama operasi yaitu masih ditemukannya ketidaksetaraan antara para pihak yang masuk dalam kerja sama operasi yaitu antara kewajiban, modal dan resiko tidak sesuai dengan pembahian pekeraan dan keuntungan.

Perlu adanya pemahaman dan sosialisasi bagi anggota Gapensi Kota Semarang mengenai makna penting keseimbangan dan kesetaraan dalam perjanjian kemitraan. Adanya ketidakseimbangan dan kesetaraan dalam perjanjian sangat rentan adanya pembatalan perjanjian oleh pengadilan. Hal ini yang masih banyak belum diketahui oleh anggota Gapensi Kota Semarang.

\section{E. PENUTUP}

Perlindungan hukum dalam perjanjian kemitraan pengadaan barang/jasa pemerintah ini berarti dapat memberikan kepastian hukum bagi para pihak. Perlindungan hukum perjanjian kemitraan pengadaan barang/jasa pemerintah telah diatur dalam KUH Perdata, Undang-Undang No 2 Tahun 2017 tentang Jasa Konstruksi, Undang-Undang No 20 Tahun 2009 tentang UMKM dan Peraturan Pemerintah No 17 Tahun 2013 tentang Pelaksanaan Undang-Undang No 20 Tahun 2008 tentang UMKM, Perpres No 16 Tahun 2018 tentang Pengadaan Barang/Jasa Pemerintah dan Peraturan LKPP No 9 Tahun 2018 Tentang Pedoman Pelaksanaan Pengadaan Barang/Jasa Melalui Penyedia. Perlindungan tersebut berupa keharusan perjanjian kemitraan harus dibuat secara tertulis sebagai usaha untuk menghindari adanya perselisihan dan sengketa dan diakuinya perjanjian kemitraan sebagai bukti pengalaman pekerjaaan yang sangat bermanfaat bagi UMKM. Kelemahan perjanjian kemitraan yaitu masih adanya disharmonisasi pengaturan tentang perjanian kemitraan, sehingga para penyedia jasa konstruksi menagalami kesulitan pada saat pelaksanna tender pengadaan barang/jasa pemerintah. 
Saran kepada pemerintah agar adanya harmonisasi pengaturan tentang kemitraan sehingga tidak menimbulkan multi tafsir dari pengaturan tersebut. Pemerintah agar lebih meningkatkan sosialisasi mengenai pentingnya perjanjian dan kemitraan agar dalam pelaksanaan perjanian kemitraan lebih seimbang dan setara bagi para pihak. Saran kepada dunia usaha agar dalam melaksanakan perjanjian kemitraan harus dilaksanakan secara seimbang, adil dan obyektif mengenai hak dan kewajiban para pihak.

\section{DAFTAR PUSTAKA}

\section{BUKU}

Agus G Kartasasmita, "Makalah Pengadaan Barang dan Jasa Menurut Pelaku Usaha”, Jakarta, 2006, Bappenas.

Lexy J. Moleong, Metodologi Penelitian Kualitatif Edisi Revisi, PT. Remaja Rosdakarya, 2004, Bandung.

Shidarta, Hukum Perlindungan Konsumen Indonesia, Jakarta, 2000, Grasindo

Soerjono Soekanto dan Sri Mamudji,, Pengantar Penelitian Hukum, Jakarta, 1986, UI Press.

\section{JURNAL}

Adi Susila, Mencermati Rancangan Undang-undang Pengadaan Barang dan Jasa Pemerintah, Jurnal AKP, Volume1 Nomor 1, Bekasi, 2012, Fakultas Ilmu Sosial dan Ilmu Politik Universitas Islam 45.

DOI: https://doi.org/10.33558/akp.v1i1.572

Agri Chairunisa Isradjuningtias, "Force Majeure (Overmacht) Dalam Hukum Kontrak (Perjanjian) Indonesia", Junal Veritas et Justitia Vol 1 No 1 2015, Jilid 46 No. 1, Januari 2017, Fakultas Hukum Universitas Katolik Parahyangan, 2015, Bandung, hlm 138-139.

DOI: https://doi.org/10.25123/vej.1420

Ajik Sujoko, Permasalahan Subkontrak Pada Pekerjaan Konstruksi di Pemerintah, Administrasi Law \& Governance Journal Volume 2 Issue 3, 2019, Fakultas Hukum Universitas Diponegoro, 2019, Semarang. DOI: https://doi.org/10.14710/alj.v2i3.413\%20-\%20435

Andi Putra Sitorus, Politik Hukum Perlindungan Usaha Mikro Kecil Menengah (UMKM) Dalam Masyarakat Ekonomi Asean", Doktrina: Journal of Law, Volume 1 Oktober 2018, Universitas Medan Area, Medan.

Dea Putri Fajarini, Subkontrak Dalam Pengadaan Barang/Jasa Pemerintah", Mimbar Keadilan Volume 12 Nomor 1 Februari 2019 -Juli 2019, Universitas Airlangga, 2019, Surabaya.

DOI: https://doi.org/10.30996/mk.v12i1.2168 
Mitha Miranda Sari, Kedudukan Dan Tanggung Jawab Hukum Pihak Sub Kontraktor Pada Perjanjian Pengadaan Barang/Jasa Pemerintah Jurnal Ilmiah Ilmu Hukum Kenotariatan Repertorium Volume 4 No 2 2015, Fakultas Hukum Universitas Sriwijaya, 2015, Palembang.

DOI: http://dx.doi.org/10.28946/rpt.v4i2.163

Muhammad Natsir Asnawi, "Perlindungan Hukum Kontrak Dalam Perspektif Hukum Kontrak Kontemporer", Jurnal Masalah-Masalah Hukum, Jilid 46 No. 1, Januari 2017, Fakultas Hukum Universitas Diponegoro, 2017, Semarang. DOI: $10.14710 / \mathrm{mmh} .46 .1 .2017 .55-68$

Sugiarto Raharjo Japar, "Prinsip-Prinsip Kontrak Konstruksi Indonesia", Mimbar Yustitia Vol. 2 No.2 Desember 2018, Universitas Islam Darul Ulum, 2018, Lamongan.

\section{UNDANG-UNDANG}

\section{KUH Perdata}

Undang-Undang Nomor 2 Tahun 2017 tentang Jasa Konstruksi

Undang-Undang Nomor 20 Tahun 2008 tentang Usaha Mikro Kecil dan Menengah Peraturan Presiden No 54 Tahun 2010 tentang Pengadan Barang/Jasa Pemerintah Peraturan Presiden No 16 Tahun 2018 tentang Pengadaan Barang/Jasa Pemerintah 